DOI: https://doi.org/10.36910/6775-2524-0560-2021-44-10

УДК 004.93

Сердюк Ксенія Юріївна, магістр

П'ятикоп Олена Євгенівна, к.т.н., доцент

https://orcid.org/0000-0002-7731-3051

ДВНЗ «Приазовський державний технічний університет», м. Маріуполь, Україна

\title{
ВИБІР МОДЕЛІ ПРОГНОЗУВАННЯ ІНДИВІДУАЛЬНИХ НАВАНТАЖЕНЬ ХОДЬБИ ЛЮДИНИ
}

Сердюк К. Ю., П'ятикоп О. Є. Вибір моделі прогнозування індивідуальних навантажень ходьби людини. Сучасний світ стикається з проблемою недостатньої фізичної і рухової активності людини, або гіподинамією. Особливо зараз це питання актуальне у зв' язку з пандемією Covid-19 та вимушеним переходом на дистанційну роботу та навчання. Сучасна людина в умовах популярною на сьогоднішній день сидячої роботи рухається вкрай мало. Найпростішим методом підвищення рухової активності людини є ходьба. Робота присвячується вирішенню проблеми прогнозування кількості кроків для людини 3 урахуванням його особливостей та попередніх показників. В статті наведено аналіз публікацій щодо визначення необхідної кількості кроків. Описано процес попередньої обробки реальних даних. Для моделювання в роботі обрано три методи прогнозування: метод простого усереднення (SMA), експоненціально зважене ковзне середнє (EWMA), авторегресійна інтегрована модель змінної середньої (ARIMA). Використовувані в роботі методи дозволять знайти кращий метод для прогнозування кількості майбутніх кроків людини.

Ключові слова: ходьба, крокомір, вінсорізація, прогнозування кроків, SMA, ARIMA, EWMA.

Сердюк К. Ю., Пятикоп Е. Е. Выбор модели прогнозирования индивидуальных нагрузок ходьбы человека. Современный мир сталкивается с проблемой недостаточной физической и двигательной активности человека, или гиподинамией. Особенно сейчас этот вопрос актуален в связи с пандемией Covid-19 и вынужденным переходом на дистанционную работу и учебу. Современный человек в условиях популярной на сегодняшний день сидячей работы движется крайне мало. Самым простым методом повышения двигательной активности человека является ходьба. Работа посвящается решению проблемы прогнозирования количества шагов для человека с учетом его особенностей и предыдущих показателей. В статье приведен анализ публикаций по определению необходимого количества шагов. Описан процесс предварительной обработки реальных данных. Для моделирования в работе выбраны три методы прогнозирования: метод простого усреднения (SMA), экспоненциально взвешенное скользящее среднее (EWMA), авторегрессионная интегрированная модель скользящей средней (ARIMA). Используемые в работе методы позволят найти лучший метод для прогнозирования количества будущих шагов человека.

Ключевые слова: ходьба, шагомер, винсоризация, прогнозирования шагов, SMA, ARIMA, EWMA.

Serdiuk K., Piatykop O. The choice of a model predicting the individual person's walking loads. The modern world is faced with the problem of insufficient physical and motor activity of a person, or physical inactivity. This issue is especially relevant now in connection with the Covid-19 pandemic and the forced transition to remote work and study. Modern man in the conditions of the currently popular sedentary work moves very little. The simplest method of increasing human motor activity is walking. The work is devoted to solving the problem of predicting the number of steps for a person, taking into account his characteristics and previous indicators. The article provides an analysis of publications to determine the required number of steps. The process of preliminary processing of real data is described. Three forecasting methods have been selected for modeling in the work: seasonal moving average (SMA), the exponentially weighted moving average (EWMA), and the autoregressive integrated moving average (ARIMA). The methods used in the work will allow finding the best method for predicting the number of future steps of a person.

Keywords: walking, pedometer, step prediction, winsorizing, SMA, ARIMA, EWMA.

Постановка наукової проблеми. В даний час до багатьох захворювань цивілізації додалася ще одна - гіподинамія, викликана малорухливим способом життя та зменшенням фізичної активності [1]. Основними причинами поширення малорухливого способу життя $\epsilon$ розвиток автоматичних i роботизованих технологій, доступність використання моторизованого транспорту, поширення пасивних розваг на основі сучасних IT технологій. Усе це підвищує рівень комфорту людини, спрощує її життя, але 3 тим же негативно впливає на стан фізичного здоров'я. Також однією з впливових причин $є$ поширення сидячої роботи. В цьому випадку працівник більшу частину робочого часу працює за робочим столом, комп'ютером, пультом управління тощо і не має достатньої активності в перебігу робочого дня. В кінці дня при такій роботі, у людини втомлюється тільки одна група м'язів - спини. Так само, це пасивні розваги, які мають один сценарій дій - людина сидить і дивиться.

Ситуацію посилила пандемія викликана Covid-19, яка змусила суспільство перейти на дистанційні форми навчання та роботи. Таким чином, пропала майже зовсім необхідність виходити з дому та рухатись.

Дані Всесвітньої організації охорони здоров'я BOO3 (WHO's) показують, що часто малорухома поведінка має наступні несприятливі наслідки для здоров'я: підвищене ожиріння (збільшення ваги), погіршення кардіометаболічного здоров'я, фізичної форми, зменшена тривалість сну. А також провокує серцево-судинні захворювання, діабет 2 типу тощо [1-2]. Малорухливий спосіб життя розвивається посилено і стрімко починаючи з малого віку і закінчуючи людьми похилого віку. За даними ВООЗ в світі понад $80 \%$ підлітків і більше $36 \%$ дорослих недостатньо фізично активні. Особливо це йде про населення великих міст. Якби населення Землі було більш активним, можна було б запобігти до 5 мільйонів смертей 
на рік. Люди, які недостатньо активні, мають на 20-30\% підвищений ризик смерті в порівнянні з людьми, які досить активні [2-3].

На сьогоднішній день до фізичних активностей відносять не тільки цілеспрямовані заняття різними видами спорту, але і прогулянки, ігри, домашні справи, все те що призводить до дії рух тіла. Найпростіший i ефективний метод тренувань та поліпшення здоров'я людини, це ходьба, вона доступна всім. Рухи при ходьбі сприяють зміцненню м'язів і кісток, збільшують постачання крові всіх органів і стимулює кровообіг. Так само ходьба сприяє розвитку витривалості, зміцнює фізичну форму людини і запобігає виникненню захворювань.

Одне з найпоширеніших переконань $є$ що оптимальна кількість кроків в день має бути 10000 для будь-якої людини. Але чи $є$ ця планка абсолютної для сучасного світу, з огляду на те що це число було названо ще в 70-х роках минулого століття. Також кожна людина має свої особливості: спосіб життя, стан здоров'я, вік, вид діяльності. Також після ряду тренувань зникає інтерес і мотивація в продовженні своїх тренувань і підтримки здорового способу життя. Тому знаходження індивідуальної кількості кроків в день для кожної людини є актуальною і перспективною ідеєю для реалізації.

Метою роботи $є$ дослідження моделей прогнозування для формування індивідуальних навантажень ходьби на основі показників кроків людини за певний період часу.

\section{Аналіз останніх досліджень і публікацій.}

Існує безліч критеріїв, за якими визначають спосіб життя людини. Одним 3 таких критеріїв $є$ кількість пройдених кроків в день. Це питання досліджують багато авторів. За рекомендаціями Всесвітньої організації охорони здоров'я з питання фізичної активності і малорухливого способу життя [3] дітям і підлітком (у віці 5-17 років) слід присвячувати як мінімум 60 хвилин в день заняття фізичної активності, дорослим (у віці 18-64 років) і літнім людям слід приділяти неменше 150-300 хвилин на тиждень час для середньої інтенсивності фізичного навантаження або 75-150 хвилин для високої інтенсивності фізичного навантаження.

У статті [4] автори поставили собі за мету, зрозуміти скільки кроків в день буде досить для дорослої людини. Методом їх дослідження є огляд всіх статей за ключовими словами (педометр, акселерометр, кроки і фізична активність). Отримана інформація являє собою моніторинг певної групи людей за віком і виду діяльності, за певний час і відсоток людей, які подолали певну кількість кроків. За цими результатами автори статті визначили, що люди з обмеженими можливостями і хронічними захворюваннями проходять приблизно 4000 кроків; літні люди, що старше 65 років, проходять 5000-6000 кроків; показник для дорослих людей (20-65 років) становить 7000-8000 кроків, він же дорівнює і для дітей дошкільнят. Для підлітків (12-19 років) - це 9000 кроків, а діти (6-11 років) проходять від 10000 і до 15000. В результаті автори статті зробили висновок, що приблизно 7000-8000 кроків в день $є$ розумним порогом фізичної активності, які пов'язані з поточним станом здоров'я населення.

Автори статті [5], Catrin Tudor-Locke та David R. Bassett J, пропонують класифікувати у здорових дорослих людей фізичну активність, яка визначається крокоміром, на основі минулих досліджень. Так вони поділили на 4 групи та визначили індекси: перша група - ті хто проходять менше 5000 кроків в день, вони задають в якості індексу - «індекс малорухливого способу життя»; друга група: 5000-7499 кроків в день типові для повсякденної активності, виключаючи спорт/вправи, i можуть вважатися «малоактивними»; третя група - 7500-9999 кроків, включає в себе деяку вольову діяльність, та/або підвищені вимоги до професійної діяльності, і може вважатися «в деякій мірі активним»; четверта група - ті хто проходять 10000 кроків у день, є точкою, яку використовують для класифікації людей як «активних». Особи, які роблять більш 12500 кроків у день, швидше за все, будуть класифіковані як «дуже активні». Так само автори публікації не виключають факт, того що в майбутніх досліджень, будуть включати в класифікацію фізичної активності, стан здоров'я людини (наприклад, ожиріння, серцевосудинні захворювання і діабет).

Автори публікації [6] провели дослідження серед вибірки студентів коледжу в США і описали амбулаторну фізичну активність. Вибірка складалася з 204 чоловіків і 237 жінки, віком 19-21 років. Протягом усього дослідження вони носили акселерометр з включеним циклом роботи протягом усіх годин денної активності протягом 7 днів. В результаті в середньому студенти набирали $11473 \pm 2978$ кроків в день протягом тижня. Найбільша кількість кроків було нараховано в п'ятницю $12325 \pm 4612$ кроків, а найменшу кількість кроків набирали в неділю $-9108 \pm 4600$. За статевими ознаками відмінностей не виявлено. Так само підвели підсумки, що студенти активніші в будні ніж на вихідні дні. За результатами понад 67\% відсотків студентів подолали поріг у 10 тис. кроків на день.

Метою роботи авторів [7] було вивчити взаємозв'язок між статтю людини, щоденним підрахунком кроків і показниками ожиріння у дорослих з восьми країн Латинської Америки. Проаналізувавши вибірки людей віком 18-65 років, визначили, що середня кількість кроків в день складали - 10600. Автори статті 
виміряли показник ступеня ожиріння за допомогою окружності шиї і талі, індексом маси тіла людини, $\mathrm{i}$ прийшли до висновку, що у чоловіків була значна негативна кореляція між щоденним кількістю кроків $\mathrm{i}$ масою тіла індекс і окружність талії з поправкою на вік і соціально економічний рівням, а у жінок не було значущого зв'язку ні з одним з показників ожиріння.

Деякі автори пропонують своїми дослідженнями запобігти розвитку тієї чи іншої хвороби за допомогою щоденної ходьби. Так автори статті [8] досліджували ризики розвитку остеоартрозу колінного суглоба і розглянули скільки потрібно пройти людині в день, щоб запобігти ризикам. Так результати були такими, що збільшення на 1000 кроків додатково в день, зменшують на 16\% і 18\% функціональні обмеження людини, які були пов'язані з остеоартрозом колінного суглоба і якщо кількість кроків в день перевищує 6000, то цей показник захищає від ризику розвитку цього захворювання.

Оскільки ментальне здоров'я пов'язано безпосередньо з фізичним, то автори дослідження [9] вивчали вплив 100-денної програми, що складається з 10000 кроків, на ознаки депресії, занепокоєння i стресу, а також на загальне самопочуття з використанням стандартної психологічної шкали. Результатом стало, то що при щоденній ходьбі проявляється стійкий вплив на всі показники психічного здоров'я незалежно, чи досягла людина позначки в 10000 кроків у день.

Так само автори зачіпають тему зв'язку між інтенсивністю кроків і смертністю. Так автори статті [10] вивчали це питання серед літніх жінок протягом 4 років. Група жінок носили акселерометри 7 днів на тиждень. Отриманий результат показав, що серед жінок, які в середньому робили приблизно 4400 кроків в день, рівень смертності за період спостереження був значно нижче в порівнянні з найменш активними жінками, які робили близько 2700 кроків в день. У міру збільшення кількості кроків в день рівень смертності поступово знижувався до рівня приблизно 7500 кроків в день.

Мотиваційна проблема є однією з основних в низькій фізичної активності. Тому автори дослідження [11] та [12] взяли різні підходи до дослідження цієї проблеми. Автори статті [11] дослідили вплив мобільних технологій здорового способу життя на мотивацію підлітків (13-14 років) до фізичної активності. Протягом 8 тижнів учні школи носили фітнес браслети і заповнювали анкети та давали інтерв'ю до і після тестування, які оцінювали мотиваційну регуляцію і задоволення психологічних потреб. Результатом стало, що в кінці експерименту, за опитуванням учнів, у них знизилася мотивація. Отримані дані свідчать що на початку експерименту простежено підвищення мотивації через почуття конкуренції, провини і внутрішнього тиску. Учні повідомив про те, що займалися фізичною активністю для розваги протягом 8-тижневого періоду, і рішуче повідомив, що вони були змушені займатися фізичною активністю через змагання. Також з'ясувалося, що запропонована ззовні мета фізичної активності в 10000 кроків діяла як джерело контрольованої мотивації, але ця цифра для них робила додатковий тиск, через можливої недосягненої мети.

Дослідники в статті [12] вивчили ефективність крокоміра як мотиваційного інструменту для поліпшення ходьби. Для цьому розділи учасників на дві групи: група втручання - хто слідував чотиритижневій програмі ходьби з покроковими цілями і група порівняння - ті хто слідував еквівалентної чотиритижневої програми ходьби з цілями встановленими в хвилинах. Результат був таким, що обидві групи значно збільшили кількість кроків у порівнянні з вихідним рівнем до 4 тижні без істотної різниці між групами. Однак значно більшу кількість учасників в групі втручання в порівнянні 3 групою порівняння досягли своїх цілей на 4 тижні. І далі експеримент продовжився по 52-й тиждень, в результаті тільки 2 учасника (групи втручання) з 50, заявили що носять крокомір регулярно.

Виклад основного матеріалу й обгрунтування отриманих результатів дослідження. На основі аналізу публікацій було виявлено час, за який можна отримати достатній результат для визначення подальшої активності людини. Цей показник варіюється з одного тижня до декількох місяців, тому можна сказати що досить одного тижня для визначення способу життя людини [5], але оскільки цей результат буде не достатньо повно відображати весь період активності, то для початкового наближення візьмемо період у три місяці.

В якості набору даних для подальшого вивчення взяли реальні дані користувача, безкоштовного мобільного додатку Samsung Health [13], за період активності у 5 місяців (лютий - червень 2020 року).

При експорті даних 3 додатка, отримали 26 файлів формату CSV i 4100 файлів формату JSON, які містити багато інформації з різних датчиків мобільного пристрою, підрахунку всіляких показників (наприклад, кроків, пульсу і часу тренувань). Для подальшого дослідження, нас цікавить тільки показники кроків користувача за певний період часу. 3 отриманого файлу, нас цікавить дані по початку часу активності (create_time) і кількість кроків (walk_step_count), відзначені червоним кольором відповідні колонки (Рис.1).

Експортовані дані представлені на Рис. 2. синім кольором. Як видно 3 Рис. 2 дані мають екстремальні та нульові значення, які в подальшому можуть вплинути на результат обробки. Тому щоб 
усунути вплив екстремальних значень, використовуємо вінсорізацію, тобто перетворення даних шляхом обмеження певного кордона, щоб усунути вплив викидів. Так встановили граничну межу для отриманих даних більше верхнього на $20 \%$ і нижнього на $30 \%$, в подальшому для більшої кількості даних показник для нижньої межі встановимо 50\%.

\begin{tabular}{|c|c|c|c|c|c|}
\hline create_time & source_info & speed & distance & calorie & walk_step_count \\
\hline $2020-01-27$ 12:10:4 & c20b6948-ba3a-4b5 & 1.2636039 & 7812.14 & 414.57 & 10553 \\
\hline $2020-01-306: 29: 24$ & $5003872 d-f d 4 c-4 c b 1$ & 1.363059 & 13136.46 & 714.05 & 17009 \\
\hline $2020-01-28 \quad 22: 21: 3$ & & 3.0840595 & 7821.81 & 417.31998 & 10309 \\
\hline $2020-01-2722: 00: 0$ & & 2.138889 & 7812.14 & 414.57 & 10553 \\
\hline $2020-01-3122: 00: 0$ & & 4.7222223 & 6873.92 & 382.18 & 8882 \\
\hline $2020-01-28 \quad 6: 16: 29$ & $51 \mathrm{a} 12228-52 \mathrm{c} 5-409$ & 1.3133451 & 7821.81 & 417.31998 & 10309 \\
\hline $2020-02-0322: 00: 3$ & & 3.666667 & 13657.569 & 880.52997 & 15204 \\
\hline $2020-01-3022: 00: 1$ & & 2.772543 & 13136.46 & 714.05 & 17009 \\
\hline $2020-01-3023: 30: 2$ & $362 \mathrm{e} 36 \mathrm{~b} 1-\mathrm{d} 1 \mathrm{c} 0-431$ & 1.4406121 & 6873.92 & 382.18 & 8882 \\
\hline $2020-02-0622: 00: 0$ & & 3.083333 & 9334.58 & 506.33 & 12019 \\
\hline $2020-02-02 \quad 22: 35: 2$ & $62 \mathrm{~b} 01 \mathrm{cc} 1-\mathrm{c} 094-49 \mathrm{a}$ & 1.8564616 & 13657.569 & 880.52997 & 15204 \\
\hline 2020-02-06 9:15:15 & $7 c 1 e 79 f 3-c 8 c d-41 f 4$ & 1.3838176 & 9334.58 & 506.33 & 12019 \\
\hline $2020-01-296: 56: 35$ & $9 a 5 f 033 c-d c 50-4714$ & 1.3473431 & 10519.25 & 570.76 & 13823 \\
\hline $2020-02-09$ 10:16:0 & $30 \mathrm{bb} 44 \mathrm{~b} 7-521 \mathrm{f}-4 \mathrm{~b} 9 \mathrm{c}$ & 1.3336631 & 397.22 & 19.48 & 516 \\
\hline $2020-02-0222: 00: 0$ & & 4.2222223 & 8209.84 & 457.04 & 10852 \\
\hline $2020-01-3122: 42: 5$ & $d 52 c d 2 d 2-1680-44 d$ & 1.4153718 & 3292.96 & 179.55 & 4255 \\
\hline $2020-02-04 \quad 7: 51: 55$ & $3 b 42 c d d f-f 34 f-4922$ & 1.2786459 & 6375.59 & 341.6 & 8430 \\
\hline $2020-02-128: 18: 57$ & $4 d 9 a 58 e c-e 5 b 7-436$ & 1.4752904 & 1978.32 & 97.939995 & 2628 \\
\hline $2020-02-0522: 00: 0$ & & 2.7107856 & 9077.62 & 510.59998 & 12083 \\
\hline 2020-02-07 8:15:04 & $17209 f 44-8 c 7 a-4 f 0 f-$ & 1.6374829 & 3791.39 & 207.47 & 4557 \\
\hline $2020-02-08$ 22:00:1 & & 3.075934 & 13971.66 & 760.52997 & 18623 \\
\hline
\end{tabular}

Рис. 1. Файл користувача з підрахунком кількості кроків за кожен день.

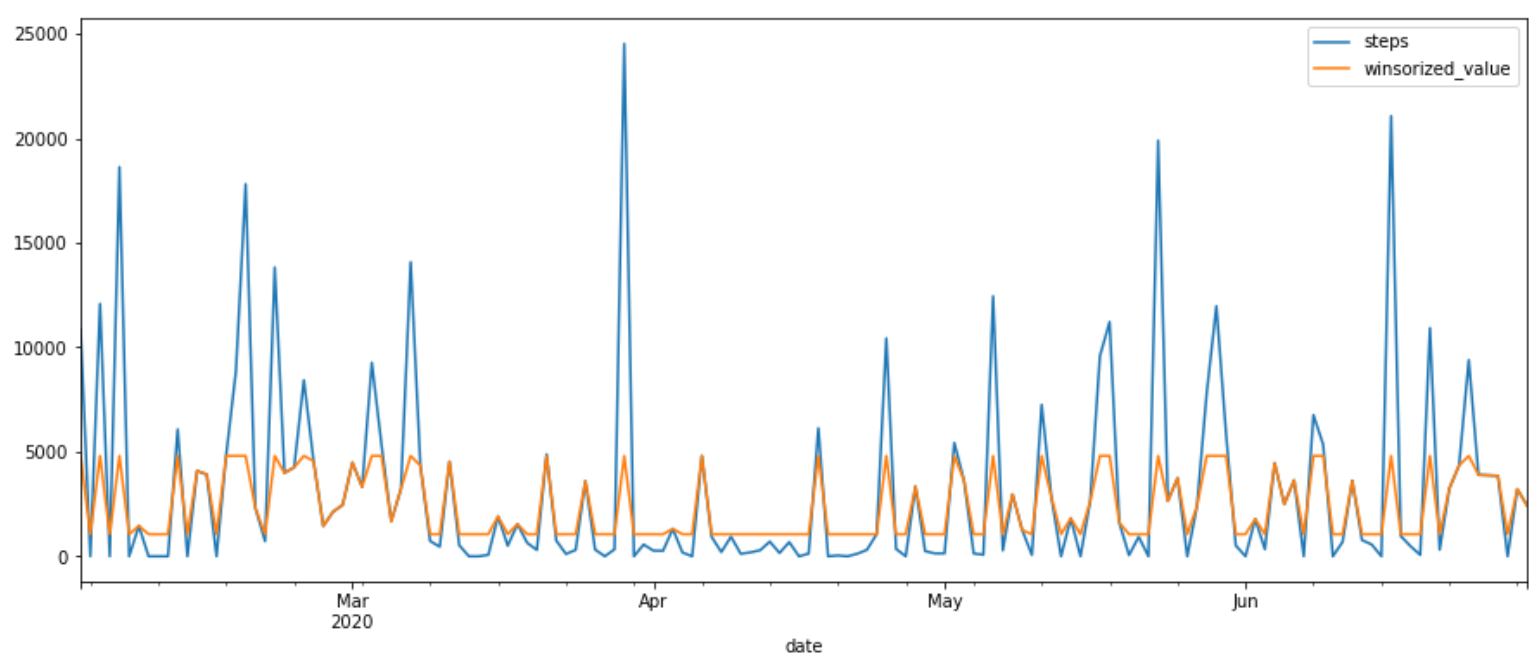

Рис. 2. Графік даних за період п’ять місяців (лютий - червень 2020 року).

Так само перевіримо дані на сезонність і загальну тенденцію, які представлені на рисунку 3 , перший графік - це отримані дані після вінсорації, другий - тренд, який визначається ковзної середньої, третій сезонність, а четвертий - діаграма розкиду залишків.

Аналіз графіків (Рис. 3.) показав, що в підрахунку кроків є сезонність даних, у вигляді періоду часу - тиждень, тобто 7 днів. Для вирішення цієї проблеми будемо використовувати прогнозування подальших результатів на основі попередніх даних. У вирішенні цієї проблеми будуть використовуватися три методи прогнозування, для того щоб визначити метод за який, якомога менше витрачається час на прогнозування і отримується найбільш точний результат. 

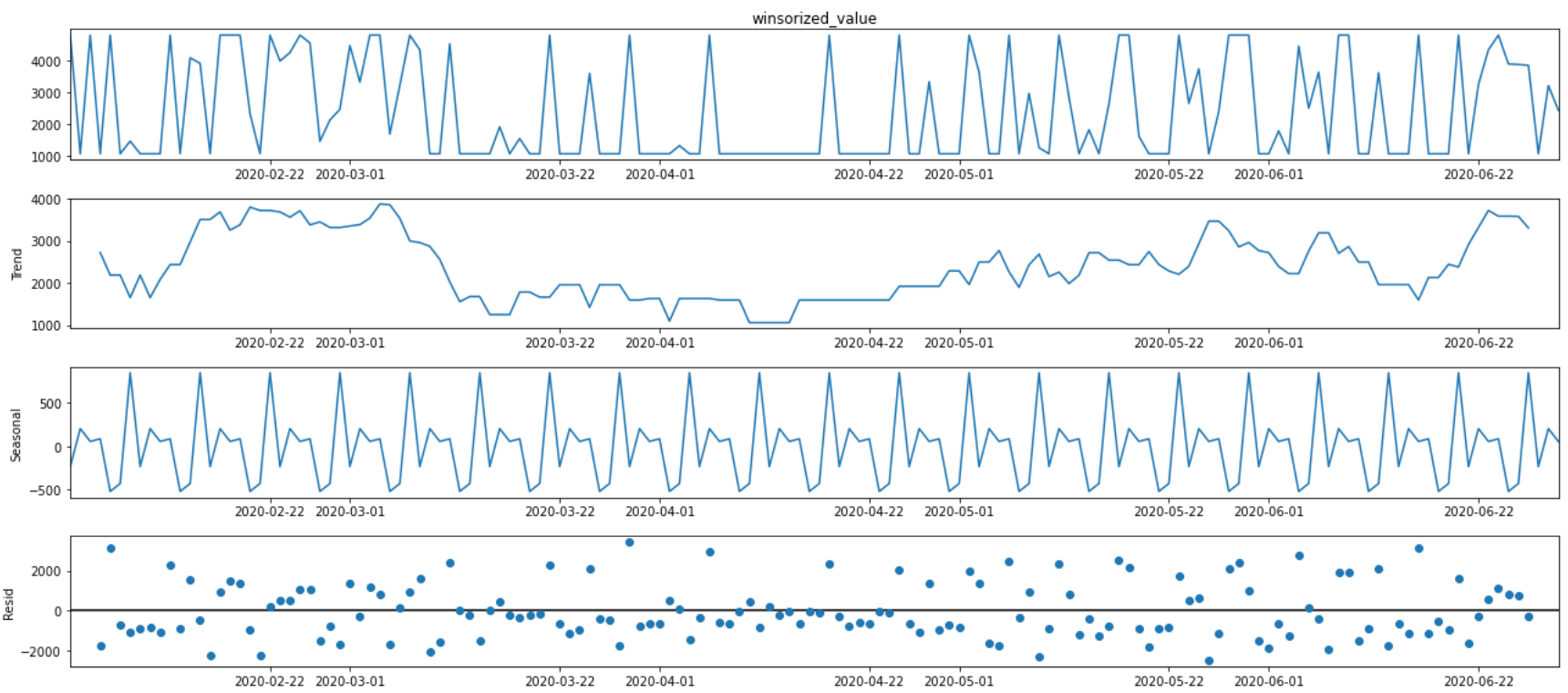

Рис. 3. Графік сезонності та загальності тенденції

Обрані методи для прогнозування:

1) Метод простого усереднення (SMA). Суть методу полягає в заміні вихідного часового ряду послідовністю середніх, що обчислюються на відрізку, який переміщається уздовж тимчасового ряду, як би ковзає по ньому. Цей метод, може допомогти згладити тенденцію зміни даних i, таким чином, дати більш реалістичний наближений результат;

2) Експоненціально зважене ковзне середнє (EWMA). Метою такого згладжування $є$ передача більшої ваги останнім значенням, і меншої ваги більш раннім. Ми можемо сказати, що тиждень, найближча до дати передбачення, повинний мати більш важку вагу, ніж просте середнє значення. Саме тоді ми можемо використовувати експоненціальне зважене ковзне середнє.

3) Авторегресійна інтегрована модель змінної середньої (ARIMA). Моделі ARIMA надають більш складні методи для моделювання трендових і сезонних компонентів, ніж інші моделі, і дозволяють (в якості додаткової переваги) включати в модель незалежні (предікторні) змінні. [14-15]

Обрані методи було застосовано для вказаного раніше періоду Дані було розділено на навчальні та тестові. Прогнозування виконувалось на останній тиждень кожного періоду. Перевірка на найкращий метод буде здійснюватися за допомогою оцінки точності прогнозування часових рядів - це середня абсолютна помилка у відсотках (MAPE) і зважена абсолютна процентна помилка (WAPE) [14-15]. Результат для прикладу прогнозування за період лютий - квітень 2020 рік наведено показано в таблиці 1.

Таблиця 1. Результат прогнозування з методами оцінки

\begin{tabular}{|l|l|l|}
\hline \multicolumn{1}{|c|}{ Методи } & WAPE & MAPE \\
\hline SMA & $26,30 \%$ & $15,25 \%$ \\
\hline EWMA & $19,39 \%$ & $3,74 \%$ \\
\hline ARIMA $(0,1,1)(0,0,0)(7)$ & $21,88 \%$ & $4,59 \%$ \\
\hline
\end{tabular}

3 таблиці видно, що для прикладу періоду лютий - квітень 2020 рік кращий метод 3 найменшою помилкою є експоненціально зважене ковзне середнє (EWMA). Але необхідно продовжити дослідження для покращення результатів.

Висновки та перспективи подальшого дослідження. В роботі описано проблему сучасного суспільства - зменшення фізичної активності людини. Зазначено, що найпростіший шлях боротьби - це щоденна ходьба. Проаналізовано останні дослідження і публікації щодо визначення необхідної кількості кроків. Але при цьому необхідно мати рекомендації для кожної людини щодо індивідуальних навантажень відповідно до особистих параметрів: спосіб життя, стан здоров'я, вік, вид діяльності. Також варто враховувати підтримку мотивації до тренувань. Тому в роботі пропонується прогнозування кількості кроків, які необхідно зробити користувачу, на основі попередніх даних.

На основі аналізу публікацій по темі здорового способу життя та активності людини протягом певного кількості часу визначено відлік початку обробки і прогнозування даних. Проведено дослідження 
реальних даних, що отримані експортуванням даних з мобільного додатку крокоміра. Визначено, що дані мають властивість сезонності і екстремальні значення. Тому для даних проведено вінсорізацію.

Для моделювання прогнозування було обрано три методи: метод простого усереднення (SMA), експоненціально зважене ковзне середнє (EWMA), авторегресійна інтегрована модель змінної середньої (ARIMA). Методи прогнозування дали такий результат, що методи простого усереднення та сезона авторегресійна інтегрована модель змінної середньої, вийшли кращими методами, на основі оцінки точності. Також модель авторегресії інтегрованого змінного середнього краще себе показує при великих відрізкав даних з великою кількістю екстремумів для цього дослідження, а метод простого усереднення для менших відрізків відповідно. Але необхідно подальше дослідження іншою кількістю даних.

\section{Список бібліографічного опису}

1. Управління охорони здоров'я: Гіподинамія: до чого може призвести брак фізичної активності? [Електронний ресурс] URL: http://www.medycyna.sm.gov.ua/index.php/uk/1207-gdhg

2. Physical activity. [Електронний ресурc] URL: https://www.who.int/news-room/fact-sheets/detail/physical-activity

3. WHO guidelines on physical activity and sedentary behaviour: at a glance. Женева: Всемирная организация здравоохранения; 2020. [Електронний ресурc] URL: https://www.who.int/publications/i/item/9789240014886

4. Tudor-Locke, C., Craig, C.L., Brown, W.J. et al. (2011) How many steps/day are enough? for adults. Int J Behav Nutr Phys Act 8, 79 .

5. Tudor-Locke C, Bassett Jr. DR. (2004) How many steps/day are enough? Preliminary pedometer indices for public health. Sports Med. 34 (1): 1-8.

6. Timothy K. Behrens and Mary K. Dinger (2005) American Journal of Health Education. 36 (4): 221-227.

7. Silvia Arribas Galagarra, Fátima Chacón-Borrego, Lzaskun Luis de Cos and Jose J. Muros Molina Int. J. Environ. (2021) Res. Public Health, 18(9), 4641.

8. White DK, Tudor-Locke C, Zhang Y, Fielding R, LaValley M, Felson DT, et al. (2014) Daily walking and the risk of incident functional limitation in kneeosteoarthritis: an observational study. Arthritis Care Res (Hoboken); 66(9):1328-36.

9. Hallam, K.T., Bilsborough, S. \& de Courten, M. (2018) "Happy feet": evaluating the benefits of a 100-day 10,000 step challenge on mental health and wellbeing. BMC Psychiatry 18, 19.

10. Lee I, Shiroma EJ, Kamada M, Bassett DR, Matthews CE, Buring JE. (2019) Association of Step Volume and Intensity WithAll-Cause Mortality in Older Women. JAMA Intern Med;179(8):1105.

11. Kerner, C.; Goodyear, V.A. (2017) The motivational impact of wearable healthy lifestyle technologies: A self-determination perspectiveon Fitbits with adolescents. Am. J. Health Educ. 48, 287-297.

12. Baker G, Mutrie N, Lowry R. (2008) Using pedometers as motivational tools: aregoals set in steps more effective than goals set in minutes for increasingwalking? Int J Health Promot Educ. 46:21-6.

13. Extract Health Data From Your Samsung Device [Електронний ресурc] / URL: https://towardsdatascience.com/extracthealth-data-from-your-samsung-96b8a2e31978

14. Бідюк, П. І. Аналіз часових рядів [Електронний ресурс] : навчальний посібник / П. І. Бідюк, В. Д. Романенко, О. Л. Тимощук ; НТУУ «КПІ». - Електронні текстові дані (1 файл: 8,42 Мбайт). - Київ : НТУУ «КПІ», 2010. - Назва 3 екрана.

15. Чумаченко Д.І., Чумаченко Т.О. Математичні моделі та методи прогнозування епідемічних процесів: монографія. Харків: ТОВ «Планета-Прінт», 2020. - $180 \mathrm{c.}$

\section{References}

1. Health Department: Physical inactivity: what can lack of physical activity lead to? URL: http://www.medycyna.sm.gov.ua/index.php/uk/1207-gdhg

2. Physical activity. URL: https://www.who.int/news-room/fact-sheets/detail/physical-activity

3. WHO guidelines on physical activity and sedentary behaviour: at a glance. Женева: Всемирная организация здравоохранения; 2020. [Електронний ресурc] URL: https://www.who.int/publications/i/item/9789240014886

4. Tudor-Locke, C., Craig, C.L., Brown, W.J. et al. (2011) How many steps/day are enough? for adults. Int J Behav Nutr Phys Act 8, 79 .

5. Tudor-Locke C, Bassett Jr. DR. (2004) How many steps/day are enough? Preliminary pedometer indices for public health. Sports Med. 34 (1): 1-8.

6. Timothy K. Behrens and Mary K. Dinger (2005) American Journal of Health Education. 36 (4): 221-227.

7. Silvia Arribas Galagarra, Fátima Chacón-Borrego, Lzaskun Luis de Cos and Jose J. Muros Molina Int. J. Environ. (2021) Res. Public Health, 18(9), 4641.

8. White DK, Tudor-Locke C, Zhang Y, Fielding R, LaValley M, Felson DT, et al. (2014) Daily walking and the risk of incident functional limitation in kneeosteoarthritis: an observational study. Arthritis Care Res (Hoboken); 66(9):1328-36.

9. Hallam, K.T., Bilsborough, S. \& de Courten, M. (2018) "Happy feet": evaluating the benefits of a 100-day 10,000 step challenge on mental health and wellbeing. BMC Psychiatry 18, 19.

10. Lee I, Shiroma EJ, Kamada M, Bassett DR, Matthews CE, Buring JE. (2019) Association of Step Volume and Intensity WithAll-Cause Mortality in Older Women. JAMA Intern Med;179(8):1105.

11. Kerner, C.; Goodyear, V.A. (2017) The motivational impact of wearable healthy lifestyle technologies: A self-determination perspectiveon Fitbits with adolescents. Am. J. Health Educ. 48, 287-297.

12. Baker G, Mutrie N, Lowry R. (2008) Using pedometers as motivational tools: aregoals set in steps more effective than goals set in minutes for increasingwalking? Int J Health Promot Educ. 46:21-6.

13. Extract Health Data From Your Samsung Device / URL: https://towardsdatascience.com/extract-health-data-from-your$\underline{\text { samsung-96b8a2e31978 }}$ 